\title{
FROM THE BORDERLAND OF THE IRON CURTAIN TO EUROPEAN AND WORLD CULTURAL HERITAGE
}

\author{
Melinda Harlov-Csortán \\ Atelier Department of European Social Sciences and Historiography \\ Eötvös Loránd University \\ Budapest, Hungary \\ e-mail:mharlov@yahoo.com
}

\begin{abstract}
Due to its location at the edge of the Iron Curtain, a constant military presence existed between today's Hungary and Austria from 1949 to 1989. The northern section of this territory is today a transnational nature park and an economically prosperous area. Most of the information materials, either on site or in publications, cover in detail the end of the military presence and reveal much less about the actual events, failed missions, and negative consequences during that almost half-century. This paper investigates this transformation by focusing on image creation between 1989, when a split appeared in the Iron Curtain in the researched territory, and 2015, when this event received international acknowledgement and appraisal in the form of the European Heritage Label. The focus is on the territory of the north-western borderland of Hungary, which became a transnational world heritage cultural landscape in 2001. The article concentrates on the social engineering processes involved in emphasising certain memories and neglecting others during the heritagisation process.
\end{abstract}

Keywords: cultural landscape, Hungary, heritagisation, Iron Curtain, memory, post-Cold War, tourism

In the sunset of dissolution, everything is illuminated by the aura of nostalgia, even the guillotine.

(Kundera 2009 [1984]: 2)

The Iron Curtain ran along the entire border (established after World War I) of Hungary and Austria in the west (356 kilometres) and after 1950 on the southern border between Hungary and Yugoslavia (627 kilometres) (Jobst 2013). It 
even split in two a lake, called Fertó or Neusiedlersee, in the north-western corner of contemporary Hungary. The area around the lake has marvellous flora and fauna, with jewellery-box-like small towns. The closeness of the economically more prosperous Austria and of the entertaining and touristy Lake Fertô/ Neusiedlersee made this part of the country tempting to settle or to establish a business after the political change in 1989. The researched landscape has earned regional, continental, and world recognition through the establishment of a transnational nature park in the early 1990s, and has received numerous awards for its environmental protection activities, gaining World Heritage status from UNESCO (2001) and the European Heritage Label by the European Council (2015). The following research discusses how this drastic change in the evaluation and characteristics of the area from a militarised, almost harsh territory to a peak region of the country happened, and what kind of memorialisation practices took place during the last approximately quarter century (Fig. 1).

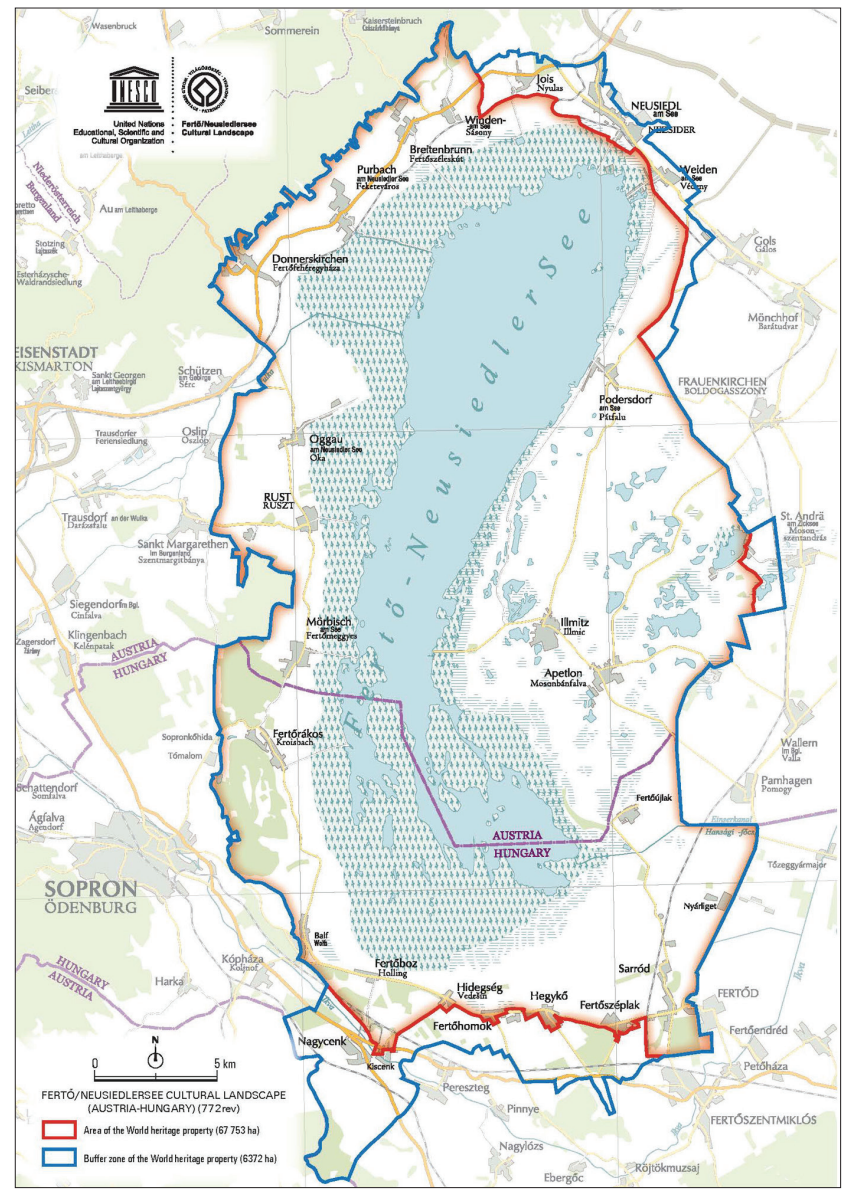

Figure 1. Map of the Fertó Cultural Landscape. Official site of the UNESCO World Heritage sites in Hungary (http: / / www.vilagorokseg. hu/fertoneusiedlerseecultural-landscape). 
First, a theoretical overview explains the views and approaches to memory, memory object and place as well as the heritagisation process along with actors who have played an important role in the presented case study. This literature review also looks into some of the former representative cases that specifically deal with the heritagisation of the socialist past, with some Eastern and Central European examples. Secondly, the border zone period of the Cold War past is introduced by focusing on the local communities, the military units and their lives. The next part of the paper, in three sections, discusses the transformation period. The first section introduces the accomplished heritagisation processes in the researched area. Those mainly tangible reminiscences from the distant past have already been acknowledged, researched and managed as important and valuable for contemporary and future generations. The second section analyses the handful of examples that commemorate the Cold War period in the territory covered by the case study. They are very different from each other in terms of owners, format, and message, and each covers a very narrow segment or defined interpretation of that half-century. The last section points out those aspects of the Cold War period that defined the researched area and still influence it but have been overlooked in the heritagisation processes. Among others, these include the everyday life, achievements, and hardships of the local communities. The concluding subchapter reviews the most important findings and points in the article.

As methodology, instead of a descriptive chronological approach an integrated analysis was undertaken. Both theoretical and literary research were carried out, and interviews were conducted with diverse actors. The location of the research was both in the capital of Hungary, where most archival materials are available, and on site, in the Fertô/Neusiedlersee area. An interdisciplinary and comparative research approach was chosen, which takes into account the different actors' diverse economic, emotional, and political opportunities and standpoints, among others. This approach enabled the complexity of the heritagisation process in the researched area to be explored.

\section{COLLECTIVE MEMORY AND PLACE: HERITAGISATION OF THE COLD WAR PERIOD}

Even though memory, in contrast with imagination, is supposed to communicate the truth of the past, there are personal, communal, circumstantial, and other factors that transform or modify memory (Keszei 2015: 14). Hence, neither a person's own nor collective memory should be understood as a clear, oneto-one copy of the past (Schacter \& Scott \& Peggy 2011: 469). Barry Schwartz 
and his colleagues (Schwartz et al. 1986: 150) emphasised the "commemorative narrative" feature of collective memory, which they defined as a story about a significant historical event that has been re-crafted many times in order to convey the envisaged moral lesson. Along these lines, it is important to mention that even though collective memory contains less information and fewer details than community members' personal memories, it has a greater impact on transforming both personal memories and the officially narrated memory of the past (Brown \& Kuori \& Hirst 2012: 2).

The materialised examples of collective memory, such as memory sites, construct a narrative about the past by contributing to its ideologisation and hierarchisation. They have the main task of exemplifying and informing the community about its interconnectedness and uniqueness (Hirst \& Manier 2008: 186). However, any place, in its complex material, symbolic and narrative aspects, also contains elements of earlier inhabitants, such as power relations, value systems, and identities. In this sense, all places carry memories due to their connections to former human experiences (Connerton 2011: 84). ${ }^{1}$ Focusing on these aspects, the understanding of a place in social studies has been enriched by adding the human perceiver aspect. It is analysed how people construct and consume locations (Lefebvre 1991: 38-43). Place is no longer considered a neutral area, but it can define actual events realised there, and the possible social activities or use of that place, based on its social perception, which refers to the memories carried by the location. In case of memorials, they say much more about the people who erected them and the contemporary evaluation of the represented past (Pótó 1989: 79) than about the particular event in the past.

Nowadays, heritagisation is one of the most common realisations of this cautious management, when a memory of the past is identified, selected, and preserved in such a way that it is maintained in everyday life and for the benefit of the contemporary community. Preserving and managing a place lead to a possible change in its perception from an unacknowledged element of the past to an active part of the social, economic, and cultural revitalisation of the present. On the other hand, many times during heritagisation changes in material objects or their configuration take place, for instance, in order to serve the needs and desires of contemporary visitors. Similarly, the general view that one can re-establish the status and conditions of a chosen time period can disturb the complexity of a place. Such drastic modifications can often happen at the time of a major social or political transformation, which often leads to a reinterpretation of the past that better serves the contemporary (political) structure and roles, and, accordingly, they also have significance with regard to the future. 
It is important to mention that diverse social units take part in memorialisation or heritagisation. Political leaders who often use memories for their own purposes (Whelan 2005: 62) unquestionably participate in the formation process. By organising celebrations for the public commemoration or cherishing a given section of the past, collaborative agreement is meant to be expressed about the narrative of the given location. Similarly, economically influential characters can define the form, material, and management of a memorial. Professionals, participants/witnesses of the given period and those who own some material remnants from the given time/event can also define the narration based on their knowledge or experience. Accordingly, not just the given memory can be complex, but so can the targeted audience, as well as the memory entrepreneurs.

After the collapse of the Iron Curtain, in an attempt to reverse decades of isolationism, many post-Soviet states resorted to the idea of the West as a terrain of renewed belonging. Katherine Verdery (1999: 35) pointed out that the post-socialist transformation involved "a reordering of people's entire meaningful worlds" and this open-ended process entailed rewriting history, forming new political arenas, and rearranging physical places. Even though many experts see the necessity of a symbolic break with the previous system, even in the form of destroying monuments or rearranging locations (Lisiak 2010), some historians (Bik 2014) have noted that these are only the first steps in changing an ideological orientation. Thus, the process of de-Sovietisation is not limited to destruction or rearrangement. Moreover, after conflicted memory sites (a term used by Sharon Macdonald 2008: 1-5) are destroyed, it might be more difficult to reconcile with the past (Jampol 2014). With the elimination of tangible memories, not only possible historical data get erased, but, and more importantly, the narrative expressed by these heritage elements and their possible effects on the society evaporate, eliminating the possibility of researching and understanding them.

Eastern European countries had different memories of the communist past (Todorova \& Dimou \& Troebst 2014: 150) due to the different historical events within the individual countries and their relations to the Soviet Union. For instance, in Hungary, between the 1960s and 1980s, a less autocratic and oppressive system operated (partly in order to prevent another revolution after 1956). That is shown in the frequently used expressions for the country: the "happiest barrack", "gulyás communism", and "fridge socialism". Memories of the last part of the Cold War period in Hungary ${ }^{2}$ were not as negative as in many other countries, such as Ukraine and the Baltic states. ${ }^{3}$ Therefore, in Eastern European countries the particular meanings attached to communism vary. For the last twenty-five years, researchers of the socialist past have faced the difficulty of evaluating that period: what should be conserved, maintained, and supported. ${ }^{4}$ 
In Hungary the fifty years of the socialist past is not seen as unquestionably positive; hence, there is a very limited heritagisation regarding that period. The focus is on the uprisings and resistance, and not on the everyday life or the local participation in the oppressive system. The events of 1956, when Hungarians rose up against the Soviet power, and 1989, when the democratic changes happened, were and are symbolically linked to each other. They are seen as decisive moments in Hungarian history, when people had to defend the sovereignty and territorial integrity of their country. The contemporary power structure (today, just like in 1989) underscores these links between the 1956 revolution and the present day, leaving out all other aspects and periods of Hungarian history in the second half of the twentieth century (Eörsi 2009: 60-62). The following sub-chapter describes a study of this transformation that happened in north-western Hungary. It was a seemingly peaceful process with universal and international acknowledgement and appraisal, but still with "grey areas" and question marks regarding the future consequences of contemporary heritage management, such as the consequences of not exploring but overshadowing the socialist past by concentrating on other historical time periods. Would the memory of the researched area have a gap in terms of local level experiences of both historical moments and daily life?

\section{HISTORICAL OVERVIEW OF THE BORDER ZONE PAST}

The Fertó/Neusiedlersee area was not a border zone before the Treaty of Trianon, which concluded World War I in 1920, as the boundary between Austria and Hungary was located much further to the west and did not have the same significance during the united Habsburg Empire period (Fig. 2). Accordingly, the border zone experience was still quite new in 1949, when the "death zone", with a fence, land mines, and a constant military presence was established, making tangible the ideological segregation of the continent. While life was supposed to continue as before, this area was almost closed off from its surroundings in every direction. All visitors were checked and monitored and more than thirty settlements, including Brennbergbánya and Óhermes, located in between the actual state border and the military zone, became dead-end villages segregated from the world.

In this area both Hungarian and Soviet soldiers ${ }^{5}$ and military camps existed from the end of World War II onwards. Even though Hungary regained its sovereignty in 1947, due to the second paragraph of the twenty-second article in the fourth part of the Peace Treaty, the Soviet Union was allowed to keep its forces in the country to ensure transit between the Soviet-controlled section 


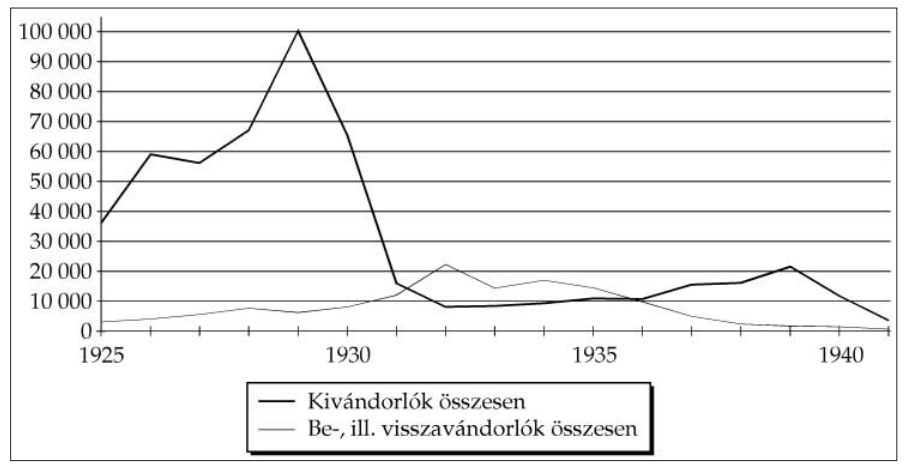

Figure 2. Annual population change and peaks thereof in Hungary in 1925-1940. The bold line shows the total number of migrants and the thin line the population change (Tarsoly 1997).

of Austria and the Soviet Union, and to do so without any defined limitation. ${ }^{6}$ Accordingly, Soviet military units occupied the already existing military locations that, ironically, had often been used by German forces. The Soviet forces located in Hungary rarely interfered in local or regional events or even with the population. They stayed in closed military camps, mainly preparing themselves for Western intervention and not for local control. Their equipment was accordingly not as high-quality or numerous. Based on original footage, their armoured cars and aeroplanes in Hungary were the ones that had been replaced in other occupied countries, such as Czechoslovakia, because they were old or obsolete (Molnár 1996: 36-46).

Austria regained its independent status in 1955; hence, the Soviet military units were supposed to leave not only that country but Hungary as well, because there was no longer a need to support transit between Austria and the Soviet Union. However, the Warsaw Pact was signed almost at the same time, which ensured the opportunity to keep Soviet forces in the member states to guarantee mutual military cooperation and assistance. After the 1956 revolution this situation changed briefly, when conditions in the country and its status were uncertain. At that time significant solidarity and collaboration among the public and some border guards made the Iron Curtain a bit porous. Right after the end of the revolution (until April 1957) 150,000-200,000 people escaped from the country through the area under study (Sallai 2012: 42). However, a new Hungarian-Soviet agreement regarding the details of the Soviet military units in Hungary was signed in 1957, with many parts of it open to further agreements, which gave relative freedom of action to the incoming Soviet troops. During the four years of cruel punishment for the revolution 
more people were prosecuted and killed than during the actual fights, and an even more rigid border control was established (Tóth \& Bank 2006). Everyday life and agricultural activities were affected by the border zone reality. Many territorial restrictions were introduced, and new technical equipment (such as more watchtowers and bombs) and more soldiers (mainly young soldiers from other parts of the country) were assigned to the border area. Fatal shooting of innocent fishermen happened regularly on Lake Fertó and nearby rivers. Fruit gardens and vineyards were destroyed by weed-killing chemicals spread by the wind from the border area (Zsiga 1999: 70-78).

The Soviet units from Austria mainly moved to the border area of Hungary, which immensely increased the size of the Soviet military presence in the area under study. The placement was quite hectic at this stage. The new Soviet military units were placed in former working camps and agricultural buildings, or the local Hungarian soldiers were moved out of their bases to accommodate the Soviet "newcomers". Even though the number of Soviet soldiers increased, they still did not interfere with the local communities. Following the plan, they were the back-up unit for a possible Western attack: Austria was considered sympathetic to the Western forces and was hence seen as a possible enemy. The type of equipment and number of Soviet troops did not enable them to act as military police forces in Hungary (Baráth 2013). Mainly trained soldiers were stationed in Hungary, whose task was to maintain the status of the equipment in case of a sudden attack. Accordingly, they rarely left their local bases.

In 1965, the "death zone" was replaced with an electronic signal system that stayed in place until 1989. The system provided electronically transmitted sound to border guards and there were spotlights to detect anyone or anything crossing the border. It did not hurt trespassers and was hence called the "gentle Iron Curtain". Even though this version of border protection caused significantly less tragedy in comparison to actual fences and land mines, it still defined the outlook and the life of the region (Fig. 3). By the late 1980s, this system did not fulfil its function successfully, as there were numerous false alarms due to animal movements, and an increasing amount of successful border-crossings occurred. The improvement or repair of the system would have been too costly for the Hungarian state. Moreover, international events and the new aims of the Hungarian political leadership, as well as the inauguration of the "world passport" in 1988, which made it possible to travel abroad, made the strong military border control redundant (Sallai 2009: 1-53). Accordingly, the leadership of the country decided to eliminate the costly electronic system, but kept the military presence with the establishment of border crossing points. The Hungarian political change of 1989, its accession to the European Union (EU) in 2004 , and then to the Schengen agreement in 2007, gradually led to smooth 


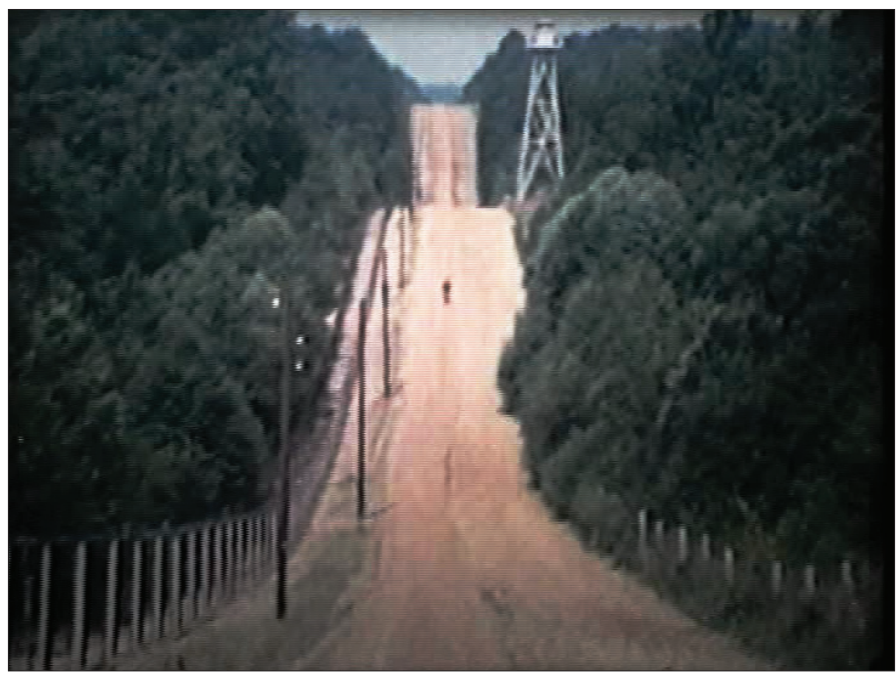

Figure 3. Hungarian Iron Curtain. Open Society Archive 394-0-1:15.

cooperation along the border. Nowadays Hungarians work daily in Austria, and Austrians have settled on the Hungarian side of the border. The area has become very popular and conditions are constantly improving for many reasons.

\section{ANALYSIS OF THE TRANSFORMATION IN THE RESEARCHED BORDER TERRITORY}

As Paul Connerton (2011: 84) explains, places incorporate former human experience and existence. The Fertó/Neusiedlersee area has also many "memorials" that allude to the previous human occupation of the territory. Diverse actors (such as locals, academic professionals, local governmental representatives, and for-profit organisations) have different ideas about what is worth protecting and propagating and what is not worthy of the heritagisation or museumisation processes. Firstly, this chapter critically introduces the pre-twentieth century elements of the past in the researched area, which are preserved in the collective memory, and then focuses on the memorialised aspects of the local Cold War experience, based on diverse actors, to emphasise the complexity of the existing memorialisation strategies. The last section discusses those elements of the Cold War period that still influence locals but for diverse reasons are not incorporated in the heritagisation process. 


\section{Memories preserved and glorified from the pre-Cold War period}

As early as ancient times, people left their marks on the researched area. Even today a Roman altarpiece exists on the contemporary Hungarian side of the border (Tóth 1971) and a trade route has been discovered in Austrian territory that historians have called the Amber Road (Navarro 1925). These archaeological findings have been researched since the 1930s and have been published widely in academic journals (see East 1932). These significant findings appeal not only to the academic community's interest, but have also been promoted by locals eager to attract tourists to the area, especially since 1989. As a result, the findings regularly appear in contemporary introductory texts about the region, published either by the local government (Wild 2000) or smaller businesses (Hárs 2000: 166). However, visitors have criticised the limited accessibility of these sites, and the lack of local directional signs and complementary services (for example, visitors' centres). ${ }^{7}$ These disadvantages decrease the potentials of memorialising the ancient past in the researched area.

One of the most prosperous periods of this region was in the eighteenth and nineteenth centuries, when significant landlords had estates in this area, which increased the value of the territory both economically and culturally. Among others, the Esterházy family ${ }^{8}$ had (and in Austria still has through their foundation) territories in this region from the Habsburg Empire period onwards. In today's Hungarian settlement called Fertôd, their "little Versailles", an architecturally outstanding estate, with a marvellous noble castle and with connected beautiful gardens, still stands. This "family centre" characterised the cultural (Joseph Haydn was an artist in residence) and economic life of the region (Gates-Coon 1994). Since 1989, the state monument protection agency has concentrated on some renovations in the researched region. A large amount of money (mainly from the state and in the last ten years partly from the EU) has been allocated to renovating the "little Versailles" (see Esterházy kastély) and the Széchenyi family's ${ }^{9}$ noble estate in Nagycenk (see Nagycenk), which are also part of the World Heritage area established in 2001. Following the investigation by William Hirst and David Manier (2008) of the uniting power of collective memory elements, both tangible heritage examples have also been nominated as official (national (Nagycenk in 2016) or historical (Fertôd in 2011)) memorial places as they "represent important Hungarian historical moments" (Nemzeti 2014). These investments have led to truly impressive results, as well as expensive entrance fees. On the other hand, there are numerous sites that carry similar or even greater significance (such as the Bishop's Palace in Fertórákos), but do not receive central state support, with no clear reason being given except for general statements of limited resources. ${ }^{10}$ Local cultural entities (such as regional museums or municipalities) are able to provide neither the necessary financial help nor any long-term management plans (Fig. 4 and 5). ${ }^{11}$ 


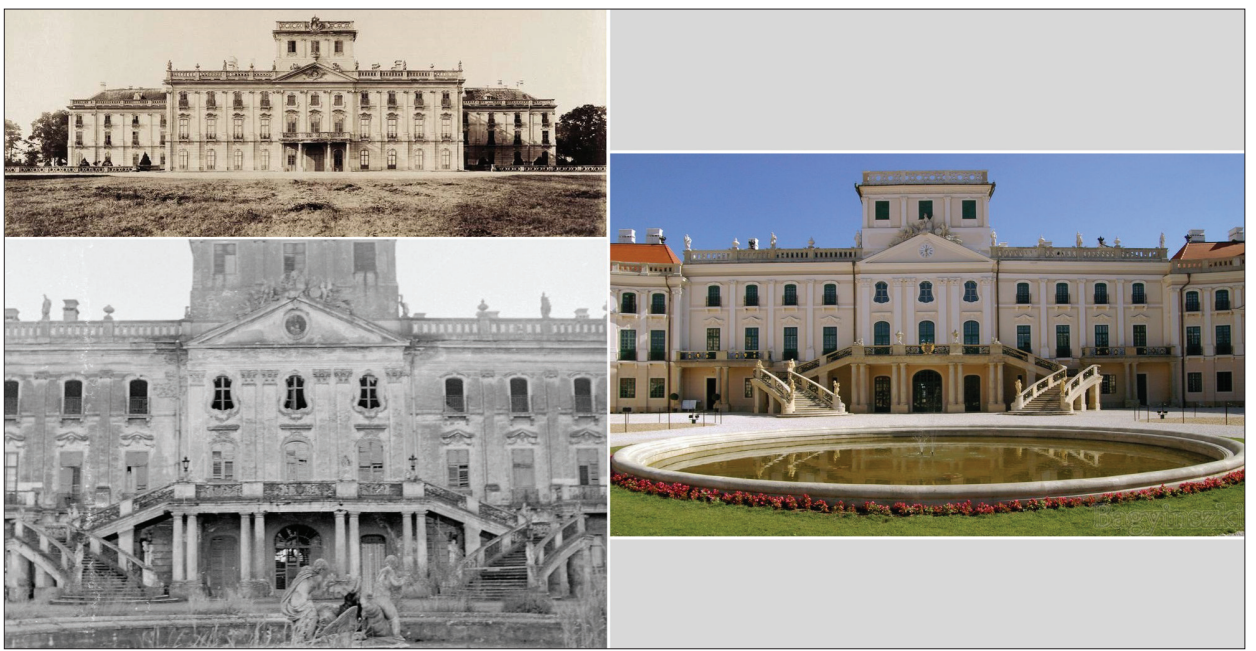

Figure 4. Monument protection on diverse levels: "little Versailles" in Fertód. Fortepan Online Photo Archive (http: / / fortepan.hu / ?view=all\&lang=en).

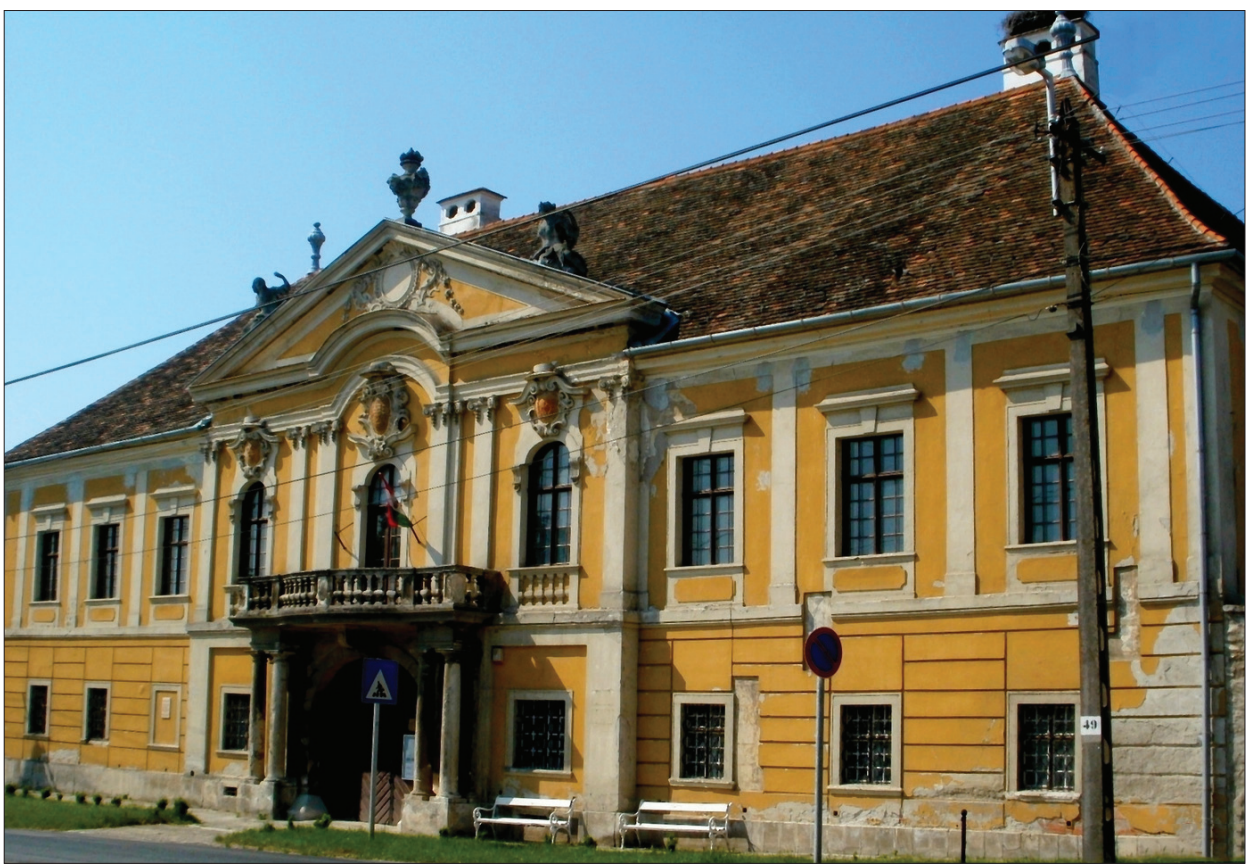

Figure 5. Bishop's Palace in Fertórákos (http:/ / www.fertorakosikirandulas.hu/fertorakos/kastely.html). 
Besides the archaeological findings and the noble tangible heritage, the vernacular architecture of the region has also been acknowledged by monument protectionist professionals since the first part of the twentieth century as monuments of the past. These buildings are seen as information sources not just regarding the given architecture, the settlement structure, the inhabitants and their lifestyles, but also regarding the cooperation among different nationalities. German-speaking minorities have been part of this region for centuries and their architecture forms a unique category that is neither Hungarian nor German/Austrian, but a special combination of the two (Fejérdy 1988). The interest of monument protection experts received political support in the Cold War period, as they were supposed to serve contemporary aims as well (Pótó 1989). Extensive and successful monument protection activities could be achieved by emphasising the political aim of exhibiting all of the positive effects of "the socialist way of life and direction" (Danubeparks Association 2000), rather than the academic and professional aims of protecting vernacular architectures typical of certain segments of the society. ${ }^{12}$ Unfortunately, there are only a handful of cases (such as in the settlements of Sarród and Fertószéplak) that have been renovated and operate as exhibition places of the local past, run by locals thanks to EU support. These would establish a role for the inhabitants in the memorialisation process, but the economic sustainability of these places and the strength of the inhabitants' voices are questionable due to the lack of proper management (Minorics 2012).

The border zone, with its settlements and, on their outskirts, the newlyerected, transformed or already existing military bases of both Hungarian and the less visible Soviet soldiers, was not just a territory to be highly protected, but also a region to show off. Accordingly, urban architecture protection also took place at its highest, national level in Sopron and Köszeg, two significant cities near the border. The restoration of Sopron's inner city was even awarded with the European Prize in 1975 (Fig. 6). These chosen "shop window" examples also became tourist destinations at the end and after the socialist period. Despite this, tourists (both national and foreign) face difficulties in exploring these sites. They have a hard time reaching these destinations, as neither public transportation nor the highways are of high quality. This is the most common concern regarding the researched area on popular social media sites and in tourism publications (such as Turista, a nature-exploring magazine). ${ }^{13}$ These problems originated in the misconception about the region in the 1990s that it was prosperous due to its closeness to the West, which was partly prevented by the lack of state funds for infrastructure support. ${ }^{14}$ 


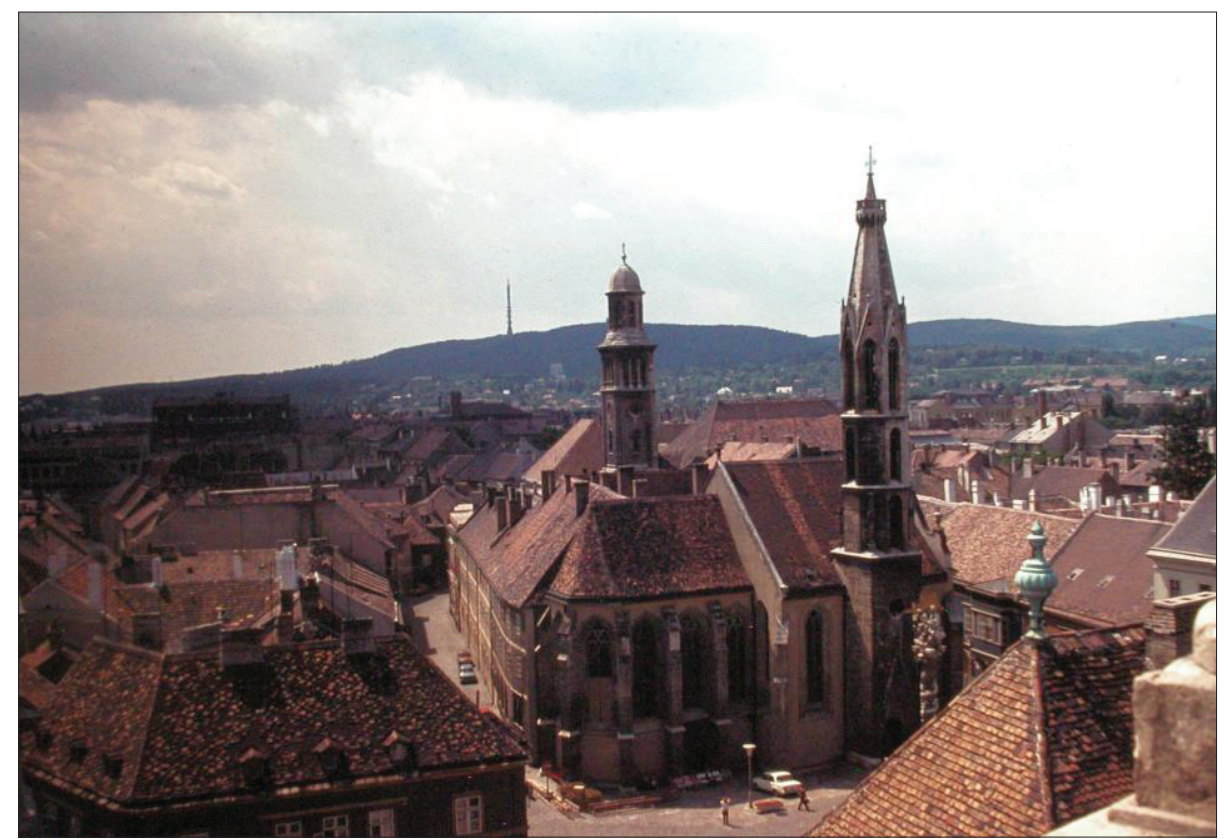

Figure 6. Sopron inner city in 1975. Fortepan Online Photo Archive ( http: / / fortepan.hu / ?view=all\&lang=en).

Despite the outstanding cultural and historical character of the researched region, it was and mainly still is an agricultural area. The connecting tangible and intangible memories of, for instance, gardening, wine-making, and fishing are significant elements of the current perception of the valuable past. Museums and tourist farms promote traditional activities among the general public, while these activities are also scientifically investigated for their sustainability and environment-protecting potentials. ${ }^{15}$ Besides fruit gardens and vineyards, the processing of reeds at Lake Fertó has been a continuous activity since the pre-World War II period. Moreover, it increased in quality and quantity during the Cold War period. Reeds as an architectural element were used not just for agricultural buildings, but for basic living constructions as well. Hungarian reeds were even sold in foreign markets, for instance, in the German Democratic Republic, and in the 1960s in the United States. By the end of the 1950s, the channel system that formed a circular shape on the lake was completed and maximised the harvest of reeds (Bognár 1966). Even though scientists have now determined that this has a major impact on the water level and is harmful to the environment (Dinka \& Ágoston-Szabó 2005), these steps led to technical improvement, significant export power, and higher employment. 
Another significant and continuing economic factor in the region was logging and the related silviculture practices as well as their industrial fields (such as work in sawmills at an industrial level, production of forestry machinery, etc.) (Csapody \& Neuwirth 1964). It is very important to emphasise that these activities were not only practised in the region, but education in these fields took place at the highest level. Moreover, the related research was conducted and published in the area as well (Zsámboki 1985: 195-210). These educational activities fostered the procedure of incorporating silviculture into the regional memorialisation processes. Today these educational institutions reflect on their past and document the present, as members of these institutions are heritage owners as well as entrepreneurs (Mastalírné 2014).

After the political change, the over-usage of nature for industrial development has stopped and nature has become "governed" by scientists instead. Academic interest in the region (its flora and fauna, as well as its architectural jewels) has been continuous, but representatives were not able to establish an institutional centre here during the Cold War period. They could only carry out shorter on-site research projects while the Iron Curtain existed. On the other hand, Austrian and Hungarian representatives did communicate with each other and commonly organised public and professional events (such as a cooperative summer camp for professionals and practitioners of environmental protection in 1985 and the first Environmental Protection Conference in Burgenland (the Austrian federal state in the border area) in 1986). They continuously supported the idea of professional cooperation and of a transnational nature park in the 1980s (Kárpáti 1990). It is very important to mention that after the fall of the Iron Curtain a great deal of international acknowledgement and support also led to improvements in the area. For example, the researched territory was chosen to be one of the RAMSAR (Wetlands of International Importance) sites in 1989 (see RAMSAR) and the Council of European Committee launched the PHARE programme (Poland and Hungary Assistance for Reconstruction of Economy) in December of the same year. Through the latter, Hungary received 1.4 million euros worth of assistance to establish the infrastructure of a national park (see PHARE).

The Hungarian national park, established in 1991, includes the south end of Lake Fertó, with its immediate surroundings, including ten settlements, the Hanság Valley to the east of the lake, two smaller lakes, and a floodplain area of the still existing wetlands in the territory of the former (much larger) Lake Fertő (see Conservation). Its Austrian counterpart, Nationalpark Neusiedler See-Seewinkel, was established in 1993, and is comprised of the major part of Lake Fertó/Neusiedlersee, the shallow saline lakes (Seewinkel), and smaller grassland areas (Nationalpark). The different legal statuses and economic 
possibilities caused some difficulties in harmonising the processes in the two countries. Both state and international support (from the World Wide Fund for Nature, for instance) had already been established on the Austrian side, while their Hungarian colleagues needed to resolve legal and territorial questions after the political change. However, the cooperation continued and, as a result, the common national park was formed in 1994 (Kárpáti 2002: 170).

After the unification, the harmonisation of aims, plans, and management directions had to be clarified. The Austrian territory of the lake had already been established as a tourist destination ("the sea of the Vienna population", as the tourist posters phrased it (Békési 2007)), while the Hungarian side could only serve the needs of biologists and environmental specialists, as neither the lake nor its immediate surroundings were in suitable condition for the same kind of leisure activities (Rakonczay 2009: 103-159). The united national park successfully applied for UNESCO World Heritage site nomination as a cultural landscape in 2001, in order to protect the current state of the territory and to maintain the balance of nature and human activities. As a result, the management of the UNESCO cultural landscape does not focus on any particular part of the past; it integrates previous practices in order to protect the still existing valuables (World Heritage 2003), an ideology that follows Jampol's (2014) view of keeping the memorials of the past as tools for facing previous time periods. For instance, reed processing has been transformed into a sustainable format and reeds serve as a natural building material for environment-conscious architectural projects.

The situation could be improved, especially in terms of better cooperation. Currently, on the Hungarian side, different entities are in charge of natural heritage, the internationally acknowledged heritage territory, national and local valuables, and the border. Yet other levels and types of institutions oversee the cultural regions and the public administration of the settlements (VÁTI Kht. 2003). The strictly protected areas are small sections spread out over a relatively wide area, which makes its proper protection and promotion very difficult (Horváth 2005: 17-22). Moreover, numerous acknowledged valuables can be found outside the protected areas, such as noble built heritage of the past, natural beauty, and the traditional lifestyle in harmony with the natural environment. Accordingly, the internationally acknowledged transnational heritage site is hardly definable in terms of location and actual value for the general public. ${ }^{16}$ 


\section{The used past: The acknowledged but not explored Cold War past}

The random examples of cultural projects, which deal with the recent past that might serve the aim of redefining the identity of the region, are very diverse in terms of scale and significance. There have been exhibitions and urban memorials dealing with the lost Jewish population of this territory (Forgotten people 2014), but empty and ruined synagogues can also be found (Kôszeg 2010). They do not have a promising future due to the lack of economic resources or possible owners. Similarly, military structures have either been completely transformed into new uses (such as a hospital in Szombathely, without even mentioning its historical significance on a plaque or through any other form of signage) or left empty, and consequently they are open to total destruction (as in the "dying" Soviet military base in Fertód) ${ }^{17}$ Many scholars (e.g. Lisiak 2010) and contemporary Hungarian representatives ${ }^{18}$ support the idea of eliminating the tangible heritage of the Soviet past as a necessity for a new start. However, the economic and social status of the region demonstrate that such a "material overthrow" alone would not lead to change (Bik 2014).

The only memorialised part of the socialist period is its ending: the successful and bottom-up initiative of 1989, which is discussed below. There are only two private museums engaged in the existence of the Iron Curtain, one dealing with the actual "death zone", and the other focusing on the electronic signal system. These private museums are basically collections of available remnants run by former border guards in Felsốcsatár and Felsốrákos (see the Iron Curtain Museum). Similar to other private initiatives of this kind in Hungary, they are not officially acknowledged as museums. These two exhibitions express pure personal memories that the owners themselves, due to their professions, collected during and immediately after the removal of control systems. The collections consist of what the owners consider worth showing, without consulting any academic or professional organisations or individuals. As Daniel Schacter, Scott Guerin, and Peggy St. Jacques (2011) explain, neither personal nor collective memory is a one-to-one copy of a particular past. Hence, these personal memories do not have more legitimacy based on first-hand experience than other memory products. Although these heritagisation projects have made the narration about the represented past richer with their unique perspectives, they are mainly neglected by the general public. They rarely attract tourists due to a lack of advertising and little knowledge of foreign languages on the part of those who run them (my own research).

The one national and, since 2015, international memorial site of the Cold War period in the researched territory is the Pan-European Picnic Memorial Park. On August 19, 1989, young politically active locals and young people 
from other cities (such as Debrecen), who shared common aims and ideas, organised a peaceful event (with an open fire, dance, and performances by folk ensembles) near the border. The aim was to express the desire for the unity of "European people" and values through a public event and a press conference. A significant number of Eastern German participants (around 600) came to the event due to the rumour that the border was going to be open. They hoped to cross the border and request Western German residence permits in Austria. Even though the border guard soldiers still had the order not to allow border crossing, they decided not to interrupt the free flow of people and the opening of the border. This was the first step (and a peaceful one) in the fall of the Iron Curtain (Kurucz 2000).

A private foundation was formed in 1989 by the organisers of the original event and by young politically active Hungarians to keep and share the memory of this particular action. Today they still provide tours and organise yearly commemorations, having also established and maintained a memorial park at the location where the Pan-European Picnic took place. Today there are numerous art pieces and information boards (Kurucz 2000: 57-58) in three languages (English, German, and Hungarian). This kind of heritagisation, in which more monuments than authentic objects can be seen and, accordingly, both the material subjects of the event and the configuration of the location have been modified, threatens the aim of protecting the memory of the historical events and might even modify them (Bendix 2009: 418).

The "commemorative narrative" of the collective memory (Schwartz et al. 1986: 150) about the Cold War period is fostered at the yearly events of the picnic (organised since 1990), when Hungarians are unified and exemplified. The Pan-European Picnic is emphasised over all other aspects of the given period as it serves the ideological aim of defining Hungarians as the initiators of the end of the Cold War. At those celebrations, Hungarian and foreign political and institutional delegates acknowledge the historical importance of the event in 1989 by joining the participants of the original occasion as well as their relatives (Pan-European Picnic). It is important to add that the location of the celebration (the Pan-European Picnic Memorial Park) is barely accessible with public transport and there are no facilities to serve the needs of the visiting general public. These factors also show the role of political leadership (Whelan 2005: 62) in this ideologically driven heritagisation process (Fig. 7).

There is also an open-air memory site of the former Iron Curtain, established in 2008 by politicians, the local government of Hegykô of 2006-2010. This memorial is located outside the settlement, in between agricultural fields, and contains information boards in two languages (Hungarian and English), and a very short segment of the fan system. Visitors might have the impression that 


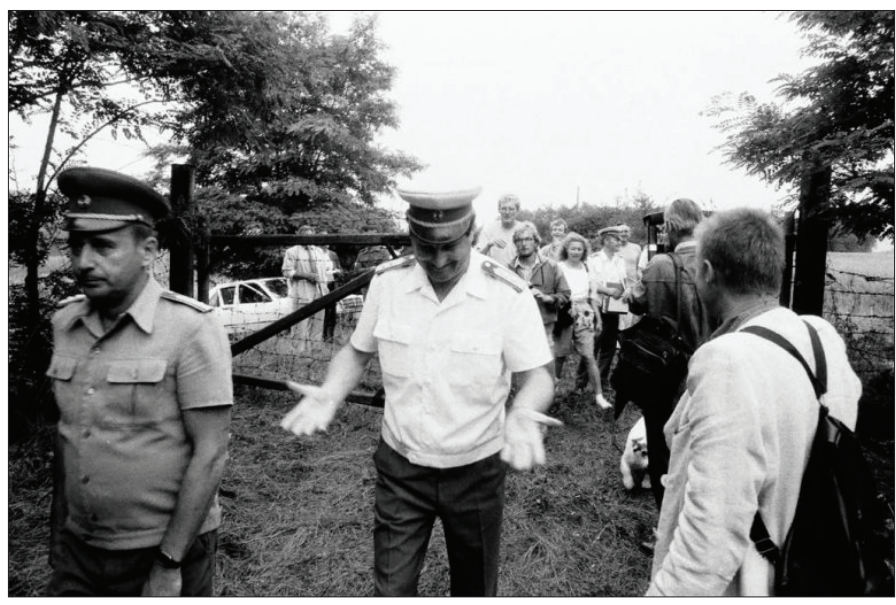

Figure 7. Pan-European Picnic 1989. Pan European Picnic Memorial Park website (http: / / www.paneuropaipiknik.hu /index.php?site=50).

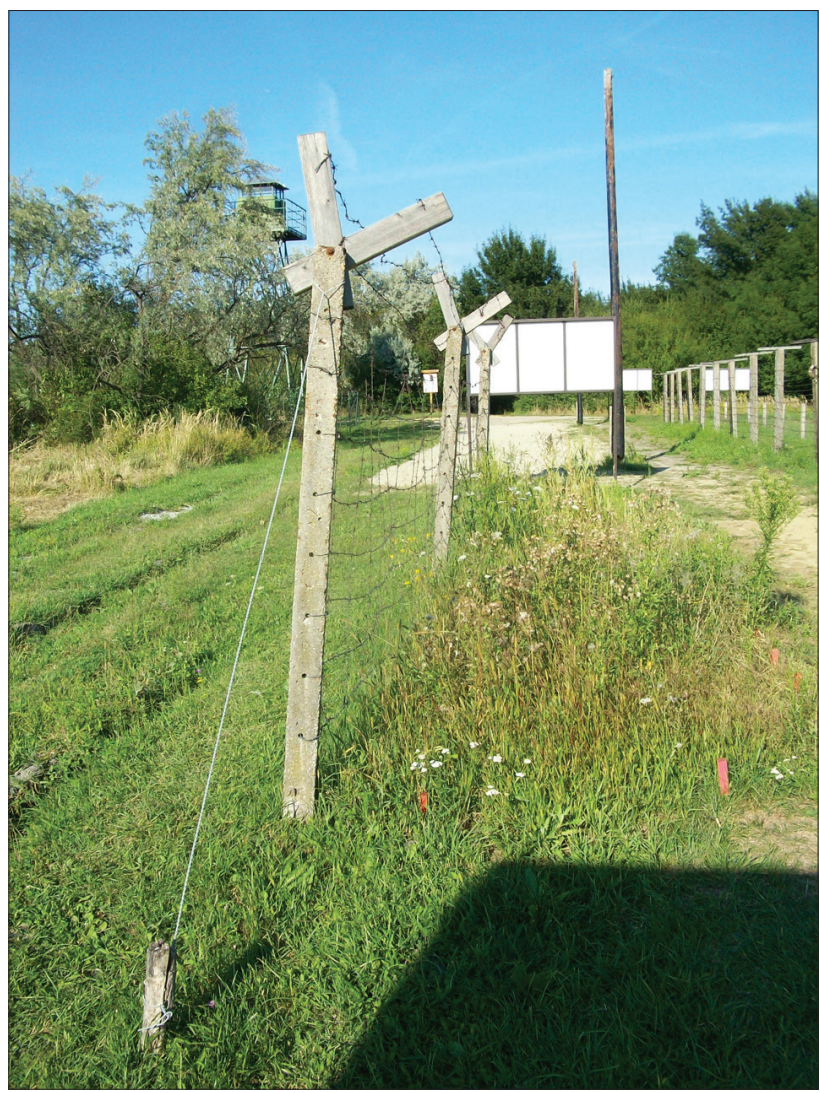

Figure 8. Hegykó Iron Curtain Memorial Site. Photograph by Melinda Harlov-Csortán 2014. 
no one has taken care of this site since its inauguration (as Keszei (2015: 10-18) points out regarding the transformation of memory due to circumstances). There is not even a sign about it within the settlement of Hegykó (Iron Curtain Memorial Site in Hegykó 2012). One can justify the lack of signs, with the authenticity of this memorial (lieux de mémoire; Nora 1986) and (at the time of its inauguration) by the assumed still strong personal and community memory of the location of the former Iron Curtain. The connected emotions and the fact that an undesirable segment of the past is memorialised here also explain its lack of significance (Fig. 8).

\section{What has not been said...}

Despite all the above described advances, the researched territory has been a border zone for almost a half century, characterised by military influence and certain restrictions on locals' opportunities. It is obvious that such circumstances, life standards, and restrictions cannot be forgotten or forgiven easily (Verdery 1999: 85). In the researched territory, through neglecting the memorialisation of these aspects of the past, forgetting is facilitated, especially for the younger generation, who has no personal memories.

The border zone experience also led to the loss of economic significance (from previously being a central zone of the monarchy to becoming a border area) and a significant decrease in standards of living. The drastic change influenced the commercial, economic, and cultural life, as well as the transportation system (Zeidler 2002). Even though an official population exchange did not happen at that time, a significant number of locals moved due to the new circumstances and the establishment of the border (Harcsa 1997: 228). Deportation decreased the population at the end of World War II. Locals with actual or assumed German origin had to leave their homes, where they had lived for generations, and this was often accompanied by harassment and nation-wide media coverage. This forced migration separated friends and families in the region. Settlements lost not just their populations, but also their status in the region, as well as connection with other cities, depending on the level of their military monitor status during the Cold War. They were either stuck between the Iron Curtain and the actual border, or had military bases in or close to them (Sallai 2009: 40). According to Attila Fersch, head of department at the Fertó-Hanság National Park, locals even today feel isolated, as there is very limited cooperation between communities along the border, even though there is no physical barrier any more. ${ }^{19}$ Many settlements have a very small population and almost no employment opportunity or economic capacity, which perpetuates their dead-end character from the past (KSH). Often Austrians buy empty houses and use them 
as summer residences, which does nothing to help energise the settlements' economic or social life. ${ }^{20}$

Former inhabitants, the German-speaking minority, did not return in significant numbers and their memories were commemorated only a decade after the political change with public art memorials (mainly in the form of statues and plaques), financed by either local political leaders or foreign representatives. Similarly, very little scientific research or academic discussion has taken place regarding the economic emigration and later forced deportation, the depressed economy or the still existing consequences of the border status and military presence (Szakolczai 2006: 141-210). Another political moment that could not be memorialised for decades due to the Soviet-supported political leadership and the hegemonic ideology of the country was the 1956 revolution and its aftermath. Only after the political change in 1989, in almost every Hungarian settlement (including the researched area), the 1956 revolution monuments were inaugurated in public spaces. However, these monuments followed general trends and not the local narratives or the specificity of the researched area. For instance, the extensive exodus has been reflected neither in publications nor in public art. ${ }^{21}$

It seems that even psychological traces of the military control can be seen. Besides the already mentioned military presence and constant monitoring (see the Open Society Archives 2016), the inhabitants also suffered from the image created of their area during the Cold War period. It was depicted in propaganda as not just an alienated, closed area, but also as the hot spot of the inner and foreign enemy. Accordingly, not only was the territory considered unattractive, but the people there were seen as suspicious (Jankó \& Tóth 2011). Even today small mirrors at the front windows invisibly reflecting the street view and curious eyes peeking out from behind curtains can be seen in the small towns and villages of the area, unlike in other Hungarian settlements. Locals prefer to hide themselves and their properties, paying minimal or no attention to neighbours or to public events. Representatives of the city of Kószeg (such as the mayor) say that the locals rarely participate in public discussions or elections. ${ }^{22}$ Even today, people in this region almost exclusively leave the products they are trying to sell in front of their houses unattended. Only a box is placed next to the product to collect money (see Turi 1995, and my own research). This practice unique to this region could be attributed to the inhabitants believing that no one would take the products without paying, as everyone is monitored by everyone in public spaces.

Besides on-site research, contemporary publications also show that the current status and identity of the region are still undefined almost three decades after the political change. If we look through marketing and introductory leaf- 
lets, brochures and books from and about the region, produced by the local municipalities, tourist offices, for-profit organisations, etc., no routes to sites are shown to help visitors explore the whole region. The only positive feature of the region that appears in these products multiple times is that it is a quiet untouched area providing a feeling of being close to nature. This feature can be understood as reminiscence and consequence of the past, the closed-in quality of the Cold War era, and the lack of any major new activity or modification since the fall of the Iron Curtain. One of the publications emphasises exactly this consequence of the Cold War period by saying: "Well-preserved thanks to its function as a border between Western Europe and the former Eastern bloc for 40 years" (Nagy 2007: 177); hence, nothing has really changed since 1989.

This natural heritage value on the Hungarian side of the lake also limits the opportunities for ecotourism, which could benefit from bicycle paths and introductory programmes. Ecotourism implies the need of local investment and intensive institutional and organisational management to fulfil the special requirements to protect the heritage. These (financial and operational tasks) have been a heavy burden on the local municipalities and the nature park (see Ecotourism). Such specified tourism also reduces the size of the target audience, the time period for touristic activities, and the number of nights that tourists can spend at one accommodation. Ecotourism in Hungary targets a specific, relatively small group, who prefers active holidays mainly in the spring and summer, when the local flora and fauna are their richest, which is exactly when environmental protection is most necessary. This type of tourism can also be characterised as involving short visits at certain locations or a chain of those through a planned route, which again is problematic since the local transportation and cooperation still have not been developed properly. Accordingly, it seems not even tourism can foster significant change on local levels by local involvement. There have only been a few attempts to adapt this relatively new type of tourism to the aim of preserving and managing local memory, for instance, by establishing and advertising the Iron Curtain bike route. This route, also part of the European Green Belt and the EuroVelo13 programmes ${ }^{23}$ leads through less touristy but historically more relevant parts of the region (Cramer 2010).

\section{CONCLUSION}

In the part of Hungary explored in this article, the memorialisation of the Cold War period is an ongoing and mainly top-down initiative. The still existing living memories are influenced by diverse local, regional, national, and even inter- 
national processes. Diverse activities have been undertaken by various actors (such as academics coming from outside the researched area, state initiatives, and local for-profit initiatives) and circumstances (depending on whether they have the necessary financial and social support). Among others these aspects, as Lefebvre (1991) emphasises, unquestionably influence the representation of the given area in the receivers' eyes. These receivers are varied: inhabitants are the target audience for the local governmental representatives, international academia are the receivers of academic research, while tourists (both national and international) are the target audience of for-profit organisations. This complex mixture of actors, aims, and approaches makes the case study unique.

The area has been acknowledged by numerous international organisations that have been crucial in the process, especially right after the political change; for instance, international support helped to harmonize the status of the two (Austrian and Hungarian) sides of Lake Fertó and led to further cooperation. On the national level, there has been significant support recently, but it involves quite focused, top-down initiatives that do not see and manage the complexity of sustainable memorialisation. While there have been some bottom-up initiatives and instances of heritagising the everyday life of the pre-Cold War period, there are very few instances that focus on the local specific conditions in the Cold War period. By not heritagising the experience of the Cold War period and the location of the Iron Curtain, the memory of the Soviet past and the people's former identity as Eastern Europeans can be undermined, especially among younger generations (see Jampol 2014). If only pre-Cold War memories are protected and managed in the researched area, a significant time period will be forgotten or overshadowed in the eyes of future generations. Moreover, by not dealing with the recent past, change cannot be realised and the locals will continue to feel that they are living in the shadow of the Iron Curtain.

The local initiatives to preserve either memories of the Cold War or the pre-twentieth century lifestyle through open-air museums or protection of vernacular architecture are promising efforts. Even though more and more civil units are involved in various aspects of tourismification, they are facing mainly economic and operational obstacles and challenges. Local municipalities and regional institutions, such as county museums, expressed interest in, and had the possibility of, playing a role in protecting and managing certain heritage elements of the region after the political change. However, in the last ten to fifteen years they have seemingly lost these opportunities either due to numerous institutional and personal changes or because of the increasing social and economic tasks they have to focus on. There are many abandoned sites of the recent past (such as the former hotel and regeneration centre in Kôszeg), which were established by local political powers, but were never brought to completion. These places are on their way to total elimination. 
Even the scholarly community experiences multiple challenges in properly fulfilling its role in the protection and heritagisation processes. Representatives of the natural sciences have been active for many decades and are capable of establishing well-functioning international relations and positions, as well as institutional centres in the researched area. Mainly due to their locations, the same organisations were assigned numerous heritage management tasks, such as raising awareness and motivating participatory actions, for which they have no capacity (lacking human and financial resources). ${ }^{24}$ Monument protection specialists and human rights experts have found it difficult to get access to the territory or to gain economic support for their projects. For example, Tamás Fejérdy, the President of ICOMOS (International Council on Monuments and Sites) Hungary, explained that locals avoid the more costly preservation of monuments, and Csaba Szilágyi, an archivist at the Open Society Archives, mentioned that oral history projects rarely receive the necessary financial support to succeed..$^{25}$

This situation of preferring the memorialisation of the pre-Cold War period over the local experience of the recent past might be based on two contradictory approaches: collective or top-down memorialisation versus personal memories. Personal memories are based on empirical knowledge, whereas top-down memories use learnt knowledge and projected images via mass education, memorials, and connected commemorations (Gyáni 2000). Individuals remember day-to-day struggles and concentrate less on the bigger picture or on the few but celebrated moments that were also dangerous. On the other hand, collective memory and state memory emphasise glorious events with reconstructions and nation-wide propaganda, more suitable to contemporary aims, as they form a more positive self-image. State rhetoric uses the prosperity and capacity of north-western Hungary as examples of sustainable improvement; hence, it has become the representation of the envisaged future for the whole nation, including the ill-suited eastern part of the country. One reason for the still unsuccessful bottom-up local heritagisation projects may be the relatively short period of the establishment of civil society and the practice of participatory action in Hungary. Accordingly, the state memories with the strongest impact have fuelled the collective identity through magnificent and heroic characters and an overall image. On the local level, the 'activated' memories of the region definitely provide economic benefits and new employment opportunities, but the evaluation of their effect on self-image cannot be measured yet. The consequences of such a bipolarised memorialisation process are still unclear. 


\section{ACKNOWLEDGEMENTS}

The research for this article was partially sponsored within the framework of the Visegrád Scholarship at Open Society Archives, and of the "TÁMOP 4.2.1.D15/1/KONV-2015-0006: The development of the innovation research base and knowledge centre in Kószeg within the educational and research network of the University of Pannonia" key project. The latter was subsidised by the European Union and Hungary and co-financed by the European Social Fund.

\section{NOTES}

1 Through personal memories or information acquired about a certain location, the given place has its acknowledged history. For instance, the socialist marching square in the Hungarian capital has no physical sign referring to that function any more, but memory still prevents locals and decision makers from agreeing on and establishing a new function.

2 The lightness, or less stressful nature, of Hungarian memories about the second part of socialism is represented especially in films such as Péter Tímár's works: Egészséges erotika 1986 ('Healthy erotica'), 6:3 avagy játszd újra Tutti 1998 ('6:3 or play it again, Tutti') and Csinibaba 1997 ('Dollybirds'), and Róbert Koltai's Csocsó avagy éljen május 1-e! 2001 ('Table soccer or happy May 1!'). Also, the history and evaluation of socialist public art examples show the same attitude (see Prohászka 1994 and Boros 2001).

${ }^{3}$ For examples of the difficulty of 'heritagising' the Soviet past, see Rasa Baločkaitè (2015) and Oleksandra Gaidai (2015: 137-154).

4 See, for instance, the publications of Miklós Kun (2012), contrasting with Tamás Krausz (2011). The same contrast can also be detected in popular culture between the existing nostalgia for certain aspects of the period, such as car brands, children tales and locations (see the Lost in Hungary documentary series) for a comparison with the outstanding popularity of the aims and motives of the 1956 revolution realised in featured films, songs, and events.

5 Based on available sources, Soviet soldiers were located in Hungary continuously from 1944 to 1991 in different numbers. By the end of the Cold War period, almost 50,000 Soviet soldiers and the same number of Soviet civil servants and their families were living in Hungary. They had approximately 27,000 vehicles at sixty military bases or cities, and at the six airports they controlled. The reason for this large number and their minimal interaction with the locals was that Hungary served as a back-up base to store necessary resources (both human and equipment) to counter a possible aggressive move from the West (Pataki 2000).

6 See the Treaty of Peace with Hungary.

7 About visitors' reports on the difficulties of finding and exploring the site see Ódor 2011 or Sacred Sites 2013. 
8 The Esterházy family was originally a Hungarian noble dynasty, whose ancestors can be traced back to the Middle Ages. They were an influential family loyal to the Habsburgs, and owned substantial estates in the country that was separated due to the Treaty of Trianon after World War I.

9 Numerous members of the Count Széchenyi family, originally from Nógrád County, have dedicated their lives to the improvement of the country and the life of its people. For example, István Széchenyi, along with others, established the Hungarian Academy of Sciences, the national library, and the Chain Bridge (a symbol of the Hungarian capital), using his own money. He is still referred to as "the greatest Hungarian".

${ }^{10}$ For a detailed analysis of the dissolving national monument protection, later called cultural heritage institution system, see Erdôsi 2000.

${ }^{11}$ Interviews with tour guides and employees of both the Bishop's Palace in Fertôrákos and the "little Versailles", in July and August 2016.

${ }^{12}$ Monument protection experts did not report on such information (for instance, the diverse minorities' unique building techniques) on the highest (governmental) level. Local party members were only introduced through the protection of "monuments of the working class". Interview with Anna Dobosyné Antall, a leading monument protection specialist, Budapest, July 2016.

${ }^{13}$ One of the most popular blogger's notes on the researched area is available at http:// regi.travellina.hu/?page=hazai\&id=46. See also Turista (http://www.turistamagazin. $\mathrm{hu} /)$.

14 The idea that western Hungary did not need state support for the political and economic change was based on statistical data (Belyó 2010); about the negative consequences of not providing state support, see Freid \& Holka 2011. Local experience supports the latter view, based on the interview conducted in February 2017 with Tamás Taschner, the former head of the regional Tourist Management Office, and currently the Secretary of the Hungarian Committee of the Fertó/Neusiedler; see the World Heritage site.

${ }^{15}$ Lászlómajor, which is operated by the Fertó-Hanság National Park as an on-site educational and communicational unit for the public, and as an integrated research and scientific centre for the institute, is a good example (see Lászlómajor).

${ }^{16}$ See the numerous surveys and research conducted at the Kôszeg Campus of the University of Pannonia regarding the sustainable development of the region and its location (see IASK).

${ }^{17}$ Fertôd is very touristy, but only due to the renovated Esterházy Castle. The military base is a part of the settlement that is turning into a ghost town.

${ }^{18}$ Numerous prestigious presenters at the national conference in Eger, Hungary, in September 2016, entitled "1956 and Socialism: Crisis and Rethinking".

19 The discussion took place at the Tourism and Cultural Landscape conference in Budapest in June 2016.

${ }^{20}$ Interview with a local guide at the open-air museum in Sarród in July 2015. 
21 The most popular films and books about these escapes have been written by nonHungarians and produced or published by foreign organisations. The bridge at Andau, Austria, which was the only available route to Austria, has been memorialised and maintained mainly through international and Austrian initiatives. Hungarian academic research dealing with this topic is scarce but relevant, focusing mainly on current (twenty-first century) perceptions of past events. A recent example is Transnational Memories - Hungarian Refugees in 1956 by the Open Society Archives (http://www.osaarchivum.org/podcast/episode1_transitional-memories_hungarianrefugees-in-1956), or the works of the 1956 Institute - Oral History Archive (http:// www.rev.hu/en).

${ }^{22}$ Interview conducted in Kôszeg in August 2016.

${ }^{23}$ More information about these initiatives is available at http://www.europeangreenbelt. org/ and http://www.eurovelo13.com/.

${ }^{24}$ Interview with István Goda, the head of the Ecotourism and Public Relations Department of the Fertó-Hanság National Park, during the three-week on-site research period in January 2017.

${ }^{25}$ Interviews conducted in Budapest in March 2016.

\section{REFERENCES}

Baločkaitè, Rasa 2015. The New Culture Wars in Lithuania: Trouble with Soviet Heritage. Cultures of History Forum. Available at http://www.cultures-of-history. uni-jena.de/debates/lithuania/the-new-culture-wars-in-lithuania-trouble-withsoviet-heritage/, last accessed on November 6, 2017.

Baráth, Magdolna 2013. Adalékok a határvédelem/határốrség második világháború utáni újjászervezéséhez. [Additions to the Reorganisation of the Hungarian Border Guard after World War II.] Betekintó, Vol. 4. Available at http://www.betekinto. hu/2013_4_barath, last accessed on November 6, 2017.

Békési, Sándor 2007. Verklärt und verachtet. Wahrnehmungsgeschichte einer Landschaft: Der Neusiedler See. Vienna: Peter Lang.

Belyó, Pál 2010. Magyarország 1989-2009: A változások tükrében. [Hungary 1989-2009: In the Light of Changes.] Budapest: Központi Statisztikai Hivatal. Available at https://www.ksh.hu/docs/hun/xftp/idoszaki/mo/mo1989_2009.pdf, last accessed on November 6, 2017.

Bendix, Regina 2009. Heritage between Economy and Politics: An Assessment from the Perspective of Cultural Anthropology. In: Laurajane Smith \& Natsuko Akagawa (eds.) Intangible Heritage. London: Routledge, pp. 253-269.

Bik, Oleksii 2014. Andrei Zubov: Rossiia v rezul'tate etoi avantiury okazalas' v polnom tupike. [Russia as a Result of this Adventure Was in a Complete Deadlock.] Glavkom.ua, June 11. Available at http://glavcom.ua/articles/20092.html, last accessed on November 7, 2017. 
Bognár, Dezsó 1966. A fertói nádgazdálkodás. [Reedbed Management at Lake Fertő.] Soproni Szemle, Vol. 20, No. 2, pp. 97-109. Available at http://epa.oszk. hu/01900/01977/00072/pdf/EPA01977_Soproni_Szemle_1966-xx-2.pdf, last accessed on November 6, 2017.

Boros, Géza 2001. Emlék / Mü. [Memory/al.] Budapest: Enciklopédia.

Brown, Adam D. \& Kouri, Nicole \& Hirst, William 2012. Memory's Malleability: Its Role in Shaping Collective Memory and Social Identity. Frontiers in Psychology, Vol. 3, pp. 1-3. http://dx.doi.org/10.3389/fpsyg.2012.00257.

Connerton, Paul 2011. The Spirit of Mourning: History, Memory and the Body. Cambridge: Cambridge University Press.

Cramer, Michael 2010. Iron Curtain Trail Part 3: Along the "Green Belt" from the GermanCzech Border to the Black Sea. Berlin: Esterbauer GmbH.

Csapody, István \& Neuwirth, János 1964. Soproni-dombvidék erdőgazdasági táj. [Forestry Landscape at the Sopron Mountains.] In: István Danszky (ed.) Nyugat-Dunántúl erdôgazdasági tájcsoport Magyarország erdôgazdasági tájainak erdófelújítási erdôtelepitési irányelvei és eljárásai. Budapest: Országos Erdészeti Fóigazgatóság, pp. 519-557.

Danubeparks Association 2000. Danubeparks - Nature Award 2000. Schloss Orth: Danubeparks Association.

Dinka, Mária \& Ágoston-Szabó, Edit 2005. Nagyüzemi aratás hatásai a fertói nádasállomány reprodukciós folyamataira. [Effects of Large-Scale Harvesting on Reproductive Processes of the Reed Vegetation at Lake Fertó.] In: Katalin Török \& Láng E. Kovácsné (eds.) Válogatás az MTA Ökológiai és Botanikai Kutatóintézet kutatási eredményeiból. Vácrátót: MTA ÖBKI, pp. 37-43.

East, William G. 1932. The Danube Route - Way in History. Economica, Vol. 37, pp. 321345. DOI: $10.2307 / 2548593$.

Eörsi, László 2009. A Corvin közi emléktáblák. [The Commemorative Plaques at Corvin Mews.] História, Vol. 9, pp. 60-62. Available at http://www.historia.hu/userfiles/ files/2009-0910/Eorsi.pdf, last accessed on November 7, 2017.

Erdősi, Péter 2000. A kulturális örökség meghatározásának kísérletei Magyarországon. [Attempts to Define Cultural Heritage in Hungary.] Regio, Vol. 11, No. 4, pp. 26 44. Available at http://www.academia.edu/6324945/A_kultur\%C3\%A1lis_\%C3\% B6r\%C3\%B6ks\%C3\%A9g_meghat\%C3\%A1roz\%C3\%A1s\%C3\%A1nak_k\%C3\%A Ds\%C3\%A9rletei_Magyarorsz\%C3\%A1gon, last accessed on November 7, 2017.

Fejérdy, Tamás 1988. A nemzetiségi kultúrák építészetének védelme Magyarországon. [Protecting Minorities' Architecture in Hungary.] In: Román András (ed.) Egri Nyári Egyetem. Népek és Nemzetek Közös Épitészeti Öröksége. Eger: TIT, pp. 12-14. Available at https://library.hungaricana.hu/hu/view/SZAK_KOHI_ Kenyee_1988/?pg=0\&layout=s, last accessed on November 14, 2017.

Freid, Monika \& Holka, Gyula 2011. A társadalmi-gazdasági változások néhány vonása az elmúlt 20 évben (1989-2009). [Some Characteristics of the Socioeconomic Changes in the Past 20 Years (1989-2009).] Statisztikai Szemle, Vol. 89, No. 1, pp. 20-49. Available at http://www.ksh.hu/statszemle_archive/2011/2011_01/2011_01_020. pdf, last accessed on November 7, 2017. 
Gaidai, Oleksandra 2015. Memoralization of Lenin: Legislation and Attitudes (On the Materials of Kyiv, Vinnytsia and Cherkasy Regions). Kyiv-Mohyla Humanities Journal, Vol. 2, pp. 137-154. https://doi.org/10.18523/kmhj51031.2015-2.137-154.

Gates-Coon, Rebecca 1994. The Landed Estates of the Esterházy Princes: Hungary during the Reforms of Maria Theresia and Joseph II. Baltimore: The Johns Hopkins University Press.

Gyáni, Gábor 2000. Emlékezés emlékezet és a történelem elbeszélése. [Remembering, Memory, and the Narration of History.] Budapest: Napvilág Kiadó.

Harcsa, István 1997. A vándorlás (migráció). [The Wandering (Migration).] In: István Tarsoly (ed.) Magyarország a XX. században: Természeti környezet, népesség és társadalom, egyházak és felekezetek, gazdaság. Szekszárd: Babits Kiadó, pp. 225231. Available at http://mek.oszk.hu/02100/02185/html/207.html\#II-225, last accessed on November 14, 2017.

Hárs, József (ed.) 2000. Mithras és Oidipusz király. [Mithras and King Oedipus.] In: Fertốrákos. Budapest: Száz magyar falu könyvesháza.

Hirst, William \& Manier, David 2008. Towards a Psychology of Collective Memory. Memory, Vol. 16, No. 3, pp. 183-200. DOI: 10.1080/09658210701811912.

Horváth, Attiláné (ed.) 2005. Örökségünk a Fertố táj. [Our Heritage is the Fertố Landscape.] Fertôd: Porpáczy Aladár Középiskola Szaktanácsadó Intézmény és Kollégium.

Jampol, Justinian A. 2014. Smashing Lenin Won't Save Ukraine. The New York Times, March 3. Available at http://www.nytimes.com/2014/03/04/opinion/smashinglenin-wont-save-ukraine.html?_r=0, last accessed on November 7, 2017.

Jankó, Ferenc \& Tóth, Imre 2011. Az osztrák-magyar határtérség történelme és politikai földrajza. [History and Political Geography of the Austro-Hungarian Border Region.] In: István Németh \& Róbert Fiziker (eds.) Ausztria a 20. században: Az életképtelen államtól a boldogok szigetéig. Budapest: L'Harmattan, pp. 377-403.

Jobst, Ágnes 2013. Vasfüggöny Magyarországon. [Iron Curtain in Hungary.] Betekintố, Vol. 2, pp. 5-7. Available at http://www.betekinto.hu/2013_2_jobst, last accessed on November 7, 2017.

Kárpáti, László 1990. A Fertối Nemzeti Park tervezete. [Planning of the Fertô National Park.] Sopron: Fertô-Hanság Nemzeti Park.

Kárpáti, László 2002. The Common Treasure of Two Countries: The Fertó-Hanság National Park. In: János Tardy (ed.) Cherishing Hungary's Heritage: National Parks and World Heritage Sites. Budapest: Természet BÚVÁR Alapítvány Kiadó, pp. 169-181.

Keszei, András 2015. Emlékek formájában. [In the Form of Memories.] Budapest: L'Harmattan.

Krausz, Tamás 2011. Vitás kérdések a Szovjetunió és Kelet-Európa XX. századi történetében. [Moot Points in the 20th Century History of the Soviet Union and Eastern Europe.] Budapest: Russica Pannonicana.

Kun, Miklós 2012. Sztálin alkonya. [Stalin's Twilight.] Budapest: Unicus.

Kundera, Milan 2009 [1984]. The Unbearable Lightness of Being. New York: Harper Perennial.

Kurucz, Gyula (ed.) 2000. Az elsố határnyitás: Sopron, 1998. augusztus 19. [The First Opening of the Border: Sopron, August 19, 1998.] Budapest: Kortárs Kiadó. 
Lefebvre, Henri 1991. The Production of Space. Oxford: Blackwell.

Lisiak, Agata Anna 2010. Urban Cultures in (Post)Colonial Central Europe. West Lafayette, IN: Purdue University Press.

Macdonald, Sharon 2008. Difficult Heritage: Negotiating the Nazi Past in Nurenberg and Beyond. Abington \& New York: Routledge.

Mastalírné, Zádor M. 2014. A Nyugat-Magyarországi Egyetem története a kezdetektól napjainkig. [The History of the University of West Hungary from the Beginning to the Present.] Könyvtárvilág, Vol. 2, No. 4. Available at http://mke.info.hu/konyvtarvilag/ category/ii_evfolyam_2014/4_szam_2014/, last accessed on November 7, 2017.

Minorics, Tünde 2012. Az Ormánság átváltozása. [The Transformation of Ormánság.] In: Anna Dobosyné Antal (ed.) Ki van itthon?: XVIII. Népi Építészeti Tanácskozás. Budapest: ICOMOS, pp. 178-185.

Molnár, György 1996. Megszállók homályban. [Invaders in the Shadow.] Beszéló, Vol. 1, No. 8, pp. 36-46. Available at http://beszelo.c3.hu/cikkek/megszallok-homalyban, last accessed on November 7, 2017.

Nagy, Csaba 2007. A Fertó-Hanság Nemzeti Park: Ahol a puszták véget érnek. [The Fertô-Hanság National Park: Where the Lowlands End.] Budapest: Alexandra Könyvkiadó.

Navarro, José M. de 1925. Prehistoric Routes between Northern Europe and Italy Defined by the Amber Trade. The Geographical Journal, Vol. 66, No. 6, pp. 481-503. DOI: 10.2307/1783003.

Nora, Pierre (ed.) 1986. Les lieux de mémoire. Vols. 1-3. Paris: Gallimard.

Ódor, Mónika 2011. Egy gyöngyszem az útszélén: A fertôrákosi Mithras-szentély. [A Pearl at the Edge of the Road: The Mithras Sanctuary in Fertórákos.] Talita, August 10. Available at http://talita.hu/magazin/egy-gyoengyszem-az-ut-szelena-fertrakosi-mithras-szentely/, last accessed on November 7, 2017.

Pataki, István 2000. A Magyarországon állomásozó szovjet csapatok létszáma, állomáshelyei és teljes kivonása. [The Number, Positions, and Total Withdrawal of Soviet Troops Stationed in Hungary.] Múltunk, Vol. 45, No. 2, pp. 222-252.

Pótó, János 1989. Emlékmúvek, politika, közgondolkodás. [Memorials, Politics, Public Opinion.] Budapest: MTA Történelemtudományi Intézete.

Prohászka, László 1994. Szoborsorsok. [Fates of Sculptures.] Budapest: Kornétás.

Rakonczay, Zoltán 2009. A természetvédelem története Magyarországon. [The History of Environment Protection in Hungary.] Budapest: Mezógazdasági Kiadó.

Sacred Sites 2013 = Sacred Sites in Hiking Boots. Travelo, October 9. Available at http:// travelo.hu/kozel/2013/10/09/szakralis_helyek/, last accessed on November 7, 2017.

Sallai, János 2009. 20 éves határnyitás: A vasfüggöny léte és vége / 20 Jahre Grenzöffnung: Bau und Fall des Eisernen Vorhangs. Budapest: Hanns-Seidel-Stiftung.

Sallai, János 2012. Egy idejét múlt korszak lenyomata: A Vasfüggöny története. [The Imprint of a Bygone Era: The Story of the Iron Curtain.] Budapest: HannsSeidel-Stiftung. Available at http://www.bm-tt.hu/assets/letolt/konyvjelzo/ AVasfuggonytortenetehudeeng.pdf, last accessed on November 7, 2017.

Schacter, Daniel L. \& Scott, Guerin A. \& Peggy, St. Jacques L. 2011. Memory Distortion: An Adaptive Perspective. Trends in Cognitive Sciences, Vol. 15, No. 10, pp. 467474. http://dx.doi.org/10.1016/j.tics.2011.08.004. 
Schwartz, Barry \& Zerubavel, Yael \& Barnett, Bernice M. \& Steiner, George 1986. The Recovery of Masada: A Study in Collective Memory. The Sociological Quarterly, Vol. 27, No. 2, pp. 147-164. Available at http://www.jstor.org/stable/4106206, last accessed on November 7, 2017.

Szakolczai, Attila 2006. Gyôr-Sopron megye. [Gyôr-Sopron County.] In: Attila Szakolczai \& László Á. Varga (eds.) A vidék forradalma, 1956. Vol. 2. Budapest: Az 1956-os Intézet, pp. 155-164.

Tarsoly, István (ed.) 1997. Magyarország a XX. Században: Természeti környezet, népesség és társadalom, egyházak és felekezetek, gazdaság. [Hungary in the 20th Century.] Available at http://mek.oszk.hu/02100/02185/html/96.html, last accessed on November 3, 2017.

Todorova, Maria \& Dimou, Augusta \& Troebst, Stefan (eds.) 2014. Remembering Communism. Private and Public Recollections of Lived Experience in Southeast Europe. Budapest: Central European University Press.

Tóth, István 1971. A fertórákosi Mithraeum újkori története. [Modern History of Mithraeum in Fertárkos.] Múemlékvédelem, Vol. 15, No. 4, pp. 235-238.

Tóth, István \& Bank, Barbara 2006. Az 1956-os forradalom Sopronban. [The 1956 Revolution in Sopron.] Soproni Szemle, Vol. 60, No. 3, pp. 249-281.

Turi, Rocco 1995. Európai falvak. [European Villages.] Cosenza: Bios.

VÁTI Kht. 2003. Management Plan of the World Heritage Site. Available at http:// www.welterbe.org/files/downloads/managementplan_en/whfns_1_english.pdf, last accessed on November 3, 2017.

Verdery, Katherine 1999. The Political Lives of Dead Bodies: Reburial and Postsocialist Change. New York: Columbia University Press.

Wild, Róbert (ed.) 2000. Bán János: Fertórákos politikai, gazdasági, egyházi és kulturális története. [János Bán: Political, Economic, Religious and Cultural History of Fertốrákos.] Fertôrákos: Fertốrákos Község Önkormányzata-Fertôrákosi Német Kisebbségi Önkormányzat.

Whelan, Yvonne 2005. Mapping Meanings in the Cultural Landscape. In: Gregory John Ashworth \& Brian J. Graham (eds.) Senses of Place: Senses of Time. Aldershot \& Burlington: Ashgate, pp. 61-71.

Zeidler, Miklós 2002. Társadalom és gazdaság Trianon után. [Society and Economy after Trianon.] Limes, Vol. 2, pp. 5-24.

Zsámboki, László 1985. Fớiskola Selmecen és Sopronban 1904-1934. [College in Selmec and Sopron between 1904 and 1934.] In: A magyarországi müszaki felsóoktatás megindulásának 250. évfordulójára. Miskolc: Nehézipari Múszaki Egyetem, pp. 195-210.

Zsiga, Tibor 1999. A “vasfüggöny” és kora / Der Eiserne Vorhang und seine Zeit. Budapest: Hanns Seidel Alapítvány. 


\section{INTERNET SOURCES}

1956 Institute - Oral History Archive. Available at http://www.rev.hu/en, last accessed on November 7, 2017.

Bishop's Palace in Fertốrákos. Available at http://www.fertorakosikirandulas.hu/ fertorakos/kastely.html, last accessed on November 3, 2017.

Esterházy kastély. [Esterházy Palace.] Available at http://www.eszterhaza.hu/kastely, last accessed on November 7, 2017.

European Green Belt. Available at http://www.europeangreenbelt.org/, last accessed on November 7, 2017.

EuroVelo13. Available at http://www.eurovelo13.com/, last accessed on November 7, 2017.

Fertód. Available at http://nori.gov.hu/tortenelmi-emlekhelyek/Fertod/fertod-esterhazykastely/, last accessed on November 7, 2017.

Conservation = Fertó-Hanság National Park: Conservation. Available at http://www. ferto-hansag.hu/en/conservation/protected-areas/national-park.html, last accessed on November 3, 2017.

Ecotourism = Fertó-Hanság National Park: Ecotourism. Available at http://www.fertohansag.hu/en/ecotourism.html, last accessed on November 3, 2017.

Fertőszéplak. Available at http://www.fertotaj.hu/hu/ferto-taji_telepulesek/fertoszeplak, last accessed on November 7, 2017.

Forgotten People 2014 = Forgotten People of Sopron. Available at http://archiv. magyarmuzeumok.hu/kiallitas/1856_elfeledett_soproniak, last accessed on November 8, 2017.

Fortepan Online Photo Archive. Available at http://fortepan.hu/?view=all\&lang=en, last accessed on November 3, 2017.

IASK = Institute of Advanced Studies, Kôszeg within University of Pannonia. Available at http://www.iask.hu/1/s/3431/kraft-kreativ-varos-es-fenntarthato-videk-kozpont, last accessed on November 7, 2017.

Iron Curtain Memorial Site in Hegykő 2012. Available at https://hegyko.hu/programok/ vasfuggony-emlekhely, last accessed on November 3, 2017.

Iron Curtain Museum. Available at http://www.fertorakosikirandulas.hu/fertorakos/ vasfuggony_muzeum.html; http://www.vasfuggonymuzeum.hu/en/contact/, both last accessed on November 7, 2017.

Kôszeg 2010 = Zsinagógamustra Kốszegen - Béres Anikó: Már kihaltak a Schey-féle lovagok. [Survey of synagogues in Kôszeg - Anikó Béres: Schey Knights Have Already Died Out.] Alon.hu, October 28. Available at http://www.alon.hu/ zsinagogamustra-koszegen-beres-aniko-mar-kihaltak-schey-fele-lovagok, last accessed on November 7, 2017.

$\mathrm{KSH}$ (Hungarian Central Statistical Office). Unemployment rate by age groups and gender between 1992 and 2016. Available at https://www.ksh.hu/docs/hun/ xstadat/xstadat_hosszu/h_qlf012a.html, last accessed on November 7, 2017.

Lászlómajor. Available at http://www.ferto-hansag.hu/hu/okoturizmus/bemutatohelyek/ bemutato-majorsag,-laszlomajor.html, last accessed on November 7, 2017.

Lost in Hungary documentary series. Available at http://www.magyarvagyok.hu/videok/ listak/dokumentumfilmek/19535-Elhagyatva-Magyarorszagon, last accessed on November 7, 2017. 
Nagycenk. Available at http://www.nagycenk.hu/index.php?site=214\#1, last accessed on November 7, 2017.

Nationalpark $=$ Nationalpark Neusiedler See-Seewinkel. Available at http://www. nationalpark-neusiedlersee-seewinkel.at/key-facts.html, last accessed on November 3, 2017.

Nemzeti 2014 = Nemzeti Örökség Intézete 2014. [National Heritage Institute.] Information about Nagycenk and Fertód as national and historical memory places. Available at http://nori.gov.hu/nemzeti-emlekhelyek/Nagycenk/nagycenk-szechenyi-kastely/, http://nori.gov.hu/tortenelmi-emlekhelyek/Fertod/fertod-esterhazy-kastely/ last accessed on November 7, 2017.

Open Society Archives. Transnational Memories - Hungarian Refugees in 1956. Available at http://www.osaarchivum.org/podcast/episode1_transitional-memories_hungarianrefugees-in-1956, last accessed on February 8, 2017.

Pan-European Picnic $=$ Pan-European Picnic Memorial Park. Available at http://www. paneuropaipiknik.hu/index.php?site $=50$, last accessed on November 3, 2017.

PHARE $=$ The PHARE Programme and the Enlargement of the European Union. Available at http://www.europarl.europa.eu/enlargement/briefings/33a2_en.htm, last accessed on November 7, 2017.

RAMSAR. Available at http://www.ramsar.org/wetland/austria, last accessed on November 3, 2017.

Regi.travellina.hu. Available at http://regi.travellina.hu/?page=hazai\&id=46, last accessed on November 7, 2017.

Sarród. Available at http://www.sarrodtajhaz.hu/, last accessed on November 7, 2017.

Treaty of Peace with Hungary. Available at https:/www.loc.gov/law/help/us-treaties/ bevans/m-ust000004-0453.pdf, last accessed on November 6, 2017.

Turista. Available at http://www.turistamagazin.hu/, last accessed on November 7, 2017.

UNESCO World Heritage sites in Hungary. Available at http://www.vilagorokseg.hu/ fertoneusiedlersee-cultural-landscape, last accessed on November 3, 2017.

World Heritage 2003 = World Heritage Fertő/Neusiedlersee Cultural Landscape. Management Plan. Available at https://www.welterbe.org/seiten/18, last accessed on November 3, 2017. 